
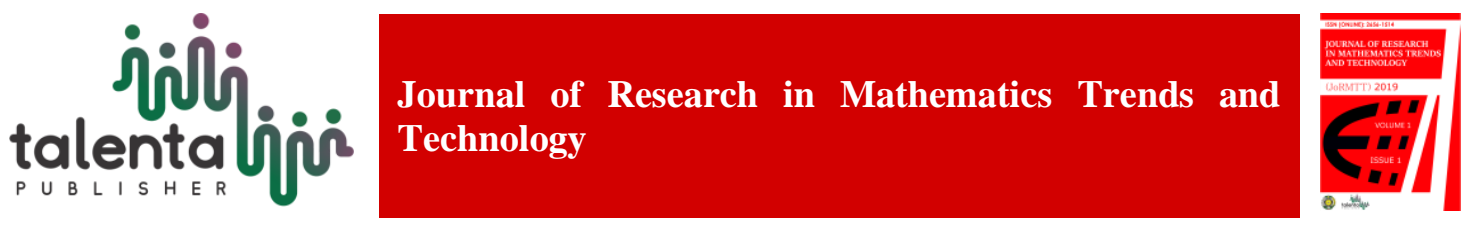

\title{
Application of Hungarian Method in Optimizing The Scheduling of Employee Assignment and Profit of Home Industry Production
}

\author{
Siti Rusdiana $^{1 *}$, Rini Oktavia ${ }^{1}$ and Empya Charlie ${ }^{1}$ \\ ${ }^{1}$ Department of Mathematics, Syiah Kuala University, Banda Aceh, Indonesia
}

\begin{abstract}
This research has a purpose to optimize the scheduling of employees in an embroidery company for doing certain tasks using Hungarian method, as well as analyzing the sensitivity of the optimal solution if there is a reduction on the employees' time to finish the tasks. The Hungarian method was applied on the assignment of workers in embroidery process involving 11 employees and 10 tasks. The optimal scheduling result minimizes the time of the embroidery production of the company. The optimal scheduling result found the optimal assignment of each worker to the tasks with the total work time is 13,7 hours. After the Hungarian method was applied, the company got the increasing revenue as much as $9,09 \%$. The sensitivity analysis was conducted by reducing the time of the employees take in embroidery the bags. The results of the sensitivity analysis are some boundaries for basis and non basis variables to maintain the optimal solution.
\end{abstract}

Keywords: Hungarian Method, Profit, Sensitivity Analysis

\begin{abstract}
Abstrak. Penelitian ini bertujuan untuk mengoptimalkan penjadwalan karyawan di perusahaan bordir untuk melakukan tugas-tugas tertentu menggunakan metode Hungarian, serta menganalisis sensitivitas solusi optimal jika ada pengurangan waktu karyawan untuk menyelesaikan tugas. Metode Hungarian diterapkan pada penugasan pekerja dalam proses bordir yang melibatkan 11 karyawan dan 10 tugas. Hasil penjadwalan yang optimal meminimumkan waktu produksi bordir perusahaan. Hasil penjadwalan yang optimal menemukan penugasan yang optimal dari setiap pekerja untuk tugas-tugas dengan total waktu kerja adalah 13,7 jam. Setelah metode Hungarian diterapkan, perusahaan mendapatkan peningkatan pendapatan sebanyak 9,09\%. Analisis sensitivitas dilakukan dengan mengurangi waktu karyawan dalam menyulam tas. Hasil analisis sensitivitas adalah beberapa batasan untuk variabel basis dan non basis untuk mempertahankan solusi optimal.
\end{abstract}

Kata Kunci: Metode Hungarian, Laba, Analisis Sensitivitas

Received 12 November 2018 | Revised 14 January 2019| Accepted 24 February 2019

\section{Introduction}

Assignment problems are special cases of the linear programming problems. Problems that are often faced in the world of management relate to optimal assignment of various productive sources. One example is the optimization of personnel assignments, which have different levels

\footnotetext{
*Corresponding author at: Syiah Kuala University, Banda Aceh, Indonesia

E-mail address: siti.rusdiana@unsyiah.ac.id
} 
of efficiency for different embroidery of hand bags assignments. One method used for optimal assignment problems is the Hungarian method [1].

In this study, the Hungarian method will be applied to a home industry engaged in the production of Aceh craft bags. The researcher will discuss about the time of assignment of employees, where each employee can be assigned to the appropriate work, so that the minimum time for the bag productions will be obtained. In this case, what you want to optimize is the assignment of the bag embroidery process.

The embroidery company consists of 11 employees who will be identified as employees 1 to employee 11, and produces 10 types of bags including, mambo bags, oblong bags, backpacks, alexa bags, floral bags, conch bags, tima bags, Luna bags, mikha bag, and elli bag, symbolized by A to J. After optimal assignment is obtained, then the next step is to analyze whether the reduction of bag fixing time will maintain the solution to be optimal or not that will be done with sensitivity analysis. Sensitivity analysis is also done to reduce and avoid recalculation if there is a change from one or several model coefficients when optimal conditions have been reached [2].

The assignment problem involves scheduling each employee on the job on a one-to-one basis. The assignment of one-to-one correspondence assigns each employee to exactly one job and each job is only assigned to one employee. The purpose of the assignment problem is to schedule each employee on the job until all work is completed in the minimum total time [3]. To apply assignment problems in special cases where the number of employees is not the same as the number of jobs to be completed, dummy employees or dummy jobs must be added so that the number of employees and the number of jobs are the same [4]. The assignment problem involves the number of employees as many as the number of jobs, say equal to $\mathrm{n}$. In this case there is $\mathrm{n}$ ! different ways to assign assignments to employees based on one-on-one assignments [5]. Hungarian method will be applied, since this method will be effective to get the result in relatively short time. Hungarian method is actually very effective if the numbers of variables involved are very large.

\section{Materials and Methods Data Collection}

Data taken at The embroidery at Dayah Daboh Village, Montasik District, Aceh. This study began in February 2017. In this study, the data taken was primary and secondary data. Some data were taken from existing data in the company. Other data were taken by interviewing each employee and observing the work of employees in embroidered bags.

\section{Data Analysis \\ Steps of the Hungarian Algorithm}

The settlement process with the Hungarian method is the first step that must be done in the form of the formation of an $n \times n$ matrix. To use the Hungarian Algorithm, first we arrange the activities and people in a matrix with rows for people, columns for activities, and entries being the time spent by employee represented by the row to embroider the bag represented by the column. Once we've done this, we make sure the number of rows equal to the number of columns by adding dummy columns or rows with entries equal to the largest cost in the entire matrix. 
After we've got our square matrix $n \times n$, the steps of the algorithm are as follows:

1. Subtract row minima - Subtract the smallest entry in each row from each entry in that row.

2. Subtract column minima - Subtract the smallest entry in each column from each entry in that column.

3. Cover all zeros with the minimum number of lines - Using the smallest number of lines possible, draw lines over rows and columns in order to cover all zeros in the matrix. If the number of lines is equal to the number of rows in your square matrix, stop here.

Otherwise, go to step 4.

4. Create additional zeros - Find the smallest element, call it $\mathrm{c}$, that is not covered by a line. Subtract $\mathrm{c}$ from all uncovered elements in the matrix and add it to any element that is covered twice. Go back to step 3.

Once we can stop the algorithm, choose a set of zeros such that each row and column only has one zero selected. Now take out any dummy rows/columns that you added. The zeros in the final matrix correspond to the ideal assignment in the original matrix.

\section{Production Benefits}

After an employee assignment optimization is carried out, a step will be taken to see the benefit obtained by comparing the benefits obtained before the Hungarian method is applied with the optimization of assignments with the Hungarian method. Sensitivity Analysis to find out whether the assignment is still optimal if a reduction in the time of assignment of employees is carried out at the length of the work process. A sensitivity analysis will be carried out to see a reduction in employee assignment time so that the solution remains optimal.

\section{Hungarian Algorithm}

Data obtained after conducting research on the company is data in the form of length of time for embroidering a particular bag in minutes by employees who work on it.

\begin{tabular}{lccccccccccccc}
\hline & & & & $\mathbf{P}$ & $\mathbf{E}$ & $\mathbf{K}$ & $\mathbf{E}$ & $\mathbf{R}$ & $\mathbf{J}$ & $\mathbf{A}$ & $\mathbf{N}$ & & \\
& & $\mathbf{A}$ & $\mathbf{B}$ & $\mathbf{C}$ & $\mathbf{D}$ & $\mathbf{E}$ & $\mathbf{F}$ & $\mathbf{G}$ & $\mathbf{H}$ & $\mathbf{I}$ & $\mathbf{J}$ \\
& $\mathbf{1}$ & 75 & 131 & 130 & 95 & 100 & 84 & 142 & 110 & 150 & 87 \\
$\mathbf{K}$ & $\mathbf{2}$ & 120 & 132 & 78 & 120 & 140 & 110 & 95 & 120 & 80 & 75 \\
$\mathbf{A}$ & $\mathbf{3}$ & 95 & 87 & 131 & 91 & 87 & 120 & 140 & 90 & 135 & 130 \\
$\mathbf{R}$ & $\mathbf{4}$ & 103 & 150 & 120 & 98 & 82 & 111 & 124 & 87 & 98 & 85 \\
$\mathbf{Y}$ & $\mathbf{5}$ & 93 & 89 & 150 & 85 & 120 & 127 & 127 & 89 & 95 & 124 \\
$\mathbf{A}$ & $\mathbf{6}$ & 121 & 147 & 88 & 126 & 128 & 96 & 110 & 89 & 95 & 97 \\
$\mathbf{W}$ & $\mathbf{7}$ & 131 & 152 & 111 & 101 & 110 & 95 & 99 & 99 & 110 & 121 \\
$\mathbf{A}$ & $\mathbf{8}$ & 75 & 81 & 82 & 120 & 82 & 84 & 145 & 98 & 90 & 87 \\
$\mathbf{N}$ & $\mathbf{9}$ & 82 & 90 & 95 & 75 & 82 & 120 & 147 & 92 & 110 & 90 \\
& $\mathbf{1 0}$ & 137 & 77 & 103 & 141 & 115 & 125 & 89 & 77 & 134 & 84 \\
& $\mathbf{1 1}$ & 110 & 136 & 131 & 91 & 82 & 84 & 127 & 140 & 80 & 77 \\
\hline
\end{tabular}

Figure 1 Duration of bag embedding (in minutes)

In the assignment problem, there is a provision that the number of rows must be equal to the number of columns $(n=m)$. From the existing data, the number of employees is not the same as 
the number of jobs $(n \neq m)$, where the number of employees is 11 and the number of jobs is 10 . For this reason, the number of $n=m$ is used to by adding dummy variables so that the assignment can be done with the Hungarian method. This problem can be formulated in linear programming as follows

$$
\operatorname{Minimum} Z=\sum_{i=1}^{11} \sum_{j=1}^{10} c_{i j} x_{i j}
$$

with the constrains:

$$
\begin{aligned}
& \sum_{i=1}^{11} x_{i j}=1 \quad j: 1,2 \ldots 10 \text { (employee constraints) } \\
& \sum_{j=1}^{10} x_{i j}=1 \quad i: 1,2 \ldots 11 \text { (job constraints) } \\
& x_{i j} \in\{0,1\} \quad \forall i \text { and } j
\end{aligned}
$$

where: $\mathrm{Z} \quad=$ Objective Function

$i \quad=$ Employee

$j \quad=$ Employee

$x_{i j} \quad=$ Employee $i$ do the work $j$

$c_{i j} \quad=$ Employee time, $i$ do the work $j$

\section{Employee Scheduling}

$$
Z=\left[\begin{array}{ccccccccccc}
75 & 131 & 130 & 95 & 100 & 84 & 142 & 110 & 150 & 87 & 0 \\
120 & 132 & 78 & 120 & 140 & 110 & 95 & 120 & 80 & 75 & 0 \\
95 & 87 & 131 & 91 & 87 & 120 & 140 & 90 & 135 & 130 & 0 \\
103 & 150 & 120 & 98 & 82 & 111 & 124 & 87 & 98 & 85 & 0 \\
93 & 89 & 150 & 85 & 120 & 127 & 127 & 89 & 95 & 124 & 0 \\
121 & 147 & 88 & 126 & 128 & 96 & 110 & 89 & 95 & 97 & 0 \\
131 & 152 & 111 & 101 & 110 & 95 & 99 & 99 & 110 & 121 & 0 \\
75 & 81 & 82 & 120 & 82 & 84 & 145 & 98 & 90 & 87 & 0 \\
82 & 90 & 95 & 75 & 82 & 120 & 147 & 92 & 110 & 90 & 0 \\
137 & 77 & 103 & 141 & 115 & 125 & 89 & 77 & 134 & 84 & 0 \\
110 & 136 & 131 & 91 & 82 & 84 & 127 & 140 & 80 & 77 & 0
\end{array}\right]
$$

Figure 2 Cost matrix

Figure 1 is arranged into a cost matrix with size $n \times n$. Then we identified the smallest cell values of each row and column. Then each entry in each row is subtracted from the smallest entry in the row in the matrix $(Z)$, which can be mathematically written for each $i$ then:

$$
c_{i j(\text { new })}=c_{i j(\text { old })}-\min \left(c_{i j}\right), \quad j=1,2, \ldots, n
$$

In the matrix $(Z)$ above, it can be seen that there are some smallest values in each column, where all the columns will be subtracted from the smallest value of each column. Mathematically can be written, for each $j$ then:

$$
c_{i j n e w)}=c_{i j(\text { old })}-\min \left(c_{i j}\right), \quad i=1,2, \ldots, n
$$




$$
Z=\left[\begin{array}{ccccccccccc}
0 & 54 & 52 & 20 & 18 & 0 & 53 & 33 & 70 & 12 & 0 \\
45 & 55 & 0 & 45 & 58 & 26 & 6 & 43 & 0 & 0 & 0 \\
20 & 10 & 53 & 16 & 5 & 36 & 51 & 13 & 55 & 55 & 0 \\
28 & 73 & 42 & 23 & 0 & 27 & 35 & 10 & 18 & 10 & 0 \\
18 & 12 & 72 & 10 & 38 & 43 & 38 & 12 & 15 & 49 & 0 \\
46 & 70 & 10 & 51 & 46 & 12 & 21 & 12 & 15 & 22 & 0 \\
56 & 75 & 33 & 26 & 28 & 11 & 10 & 22 & 30 & 46 & 0 \\
0 & 4 & 4 & 45 & 0 & 0 & 56 & 21 & 10 & 12 & 0 \\
7 & 13 & 17 & 0 & 0 & 36 & 58 & 15 & 30 & 15 & 0 \\
62 & 0 & 25 & 66 & 33 & 41 & 0 & 0 & 54 & 9 & 0 \\
35 & 59 & 53 & 16 & 0 & 0 & 38 & 63 & 0 & 2 & 0
\end{array}\right]
$$

Figure 3 Substracted cost matrix

\section{Cost Matrix Analysis}

The analysis process on the matrix $(Z)$, must have at least one cell worth zero. The next step is to draw a line in a row or column, including all entries that are worth zero.

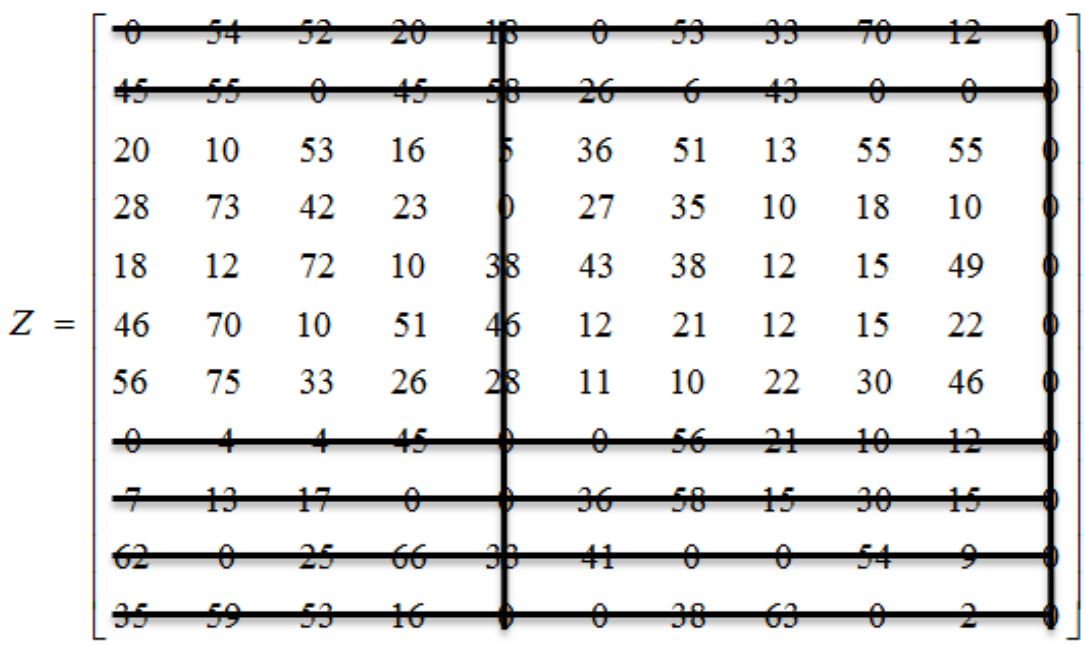

Figure 4 Cost matrix analysis 1

Since the number of rows and columns in the matrix $(Z)$ is 11 and the number of lines covering the zero entry is 8 , the number of lines is not the same as the number of rows or columns so the next step will be executed. In the matrix $(Z)$ it can be seen that the smallest value that is not covered by the line is the number 10 , then the next step is to subtract all entries that are not covered by the smallest entry and for the entry double-covered, add the value with the smallest entry, the result is as follows, 


$$
Z=\left[\begin{array}{ccccccccccc}
0 & 54 & 52 & 20 & 28 & 0 & 53 & 33 & 70 & 12 & 10 \\
45 & 55 & 0 & 45 & 68 & 26 & 6 & 43 & 0 & 0 & 10 \\
10 & 0 & 43 & 6 & 5 & 26 & 41 & 3 & 45 & 45 & 0 \\
18 & 63 & 32 & 13 & 0 & 17 & 25 & 0 & 8 & 0 & 0 \\
8 & 2 & 62 & 0 & 38 & 33 & 28 & 2 & 5 & 39 & 0 \\
36 & 60 & 0 & 41 & 46 & 2 & 11 & 2 & 5 & 12 & 0 \\
55 & 65 & 23 & 16 & 28 & 1 & 0 & 12 & 20 & 36 & 0 \\
0 & 4 & 4 & 45 & 10 & 0 & 56 & 21 & 10 & 12 & 10 \\
7 & 13 & 17 & 0 & 10 & 36 & 58 & 15 & 30 & 15 & 10 \\
62 & 0 & 25 & 66 & 43 & 41 & 0 & 0 & 54 & 9 & 10 \\
35 & 59 & 53 & 16 & 10 & 0 & 38 & 63 & 0 & 2 & 10
\end{array}\right]
$$

Figure 5 Cost matrix analysis 2

Then the next step is to draw a line to cover the zero value that has not been covered by the line and then do a re-analysis whether all the number of lines drawn is equal to the number of rows or columns that exist, if it is then the solution is optimal.

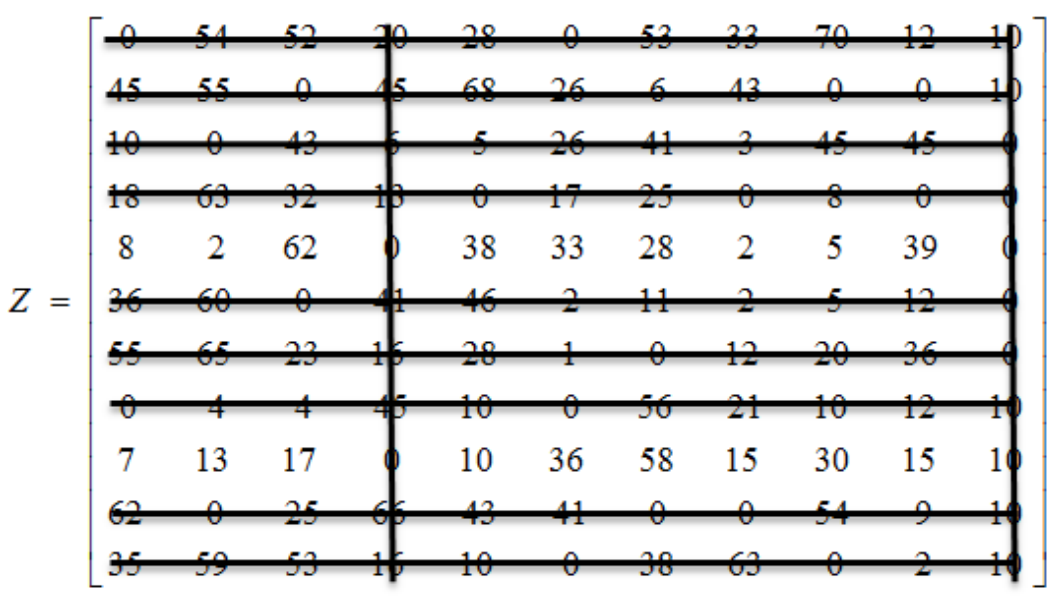

Figure 6 Cost matrix analysis 3

From the matrix $(\mathrm{Z})$ above, it can be seen that all cells with zero entries are already covered by lines and the number of rows or columns in the matrix are equal in number to the lines on the matrix. This means that if the amount is the same then the scheduling is optimal.

Table 1 Results of scheduling using the Hungarian method

\begin{tabular}{cccc}
\hline Employee & Job & Hand Bag & Working hours (Minute) \\
\hline 1 & A & Mambo & 75 \\
2 & J & Elli & 75 \\
3 & B & Lonjong & 87 \\
4 & E & Tampang Bunga & 82 \\
6 & C & Ransel & 88 \\
7 & G & Tima & 99 \\
8 & F & Keong & 84 \\
9 & D & Alexa & 75 \\
10 & H & Luna & 77 \\
11 & I & Mikha & 80 \\
Totally hours & & $\mathbf{8 2 2} / \mathbf{1 3 , 7}$ hours \\
\hline
\end{tabular}




\section{Results and Discussion}

After obtaining optimal employee assignments, then the next step is to see whether there is an influence on the benefits obtained by the company after optimal employee assignment. To see the advantages of the company, the profits before the optimization of the assignment was compared with the profit after the optimal assignment. The number of bags produced by employees ranging from embroidery to finishing in a span of 1 month can be seen in Table 2 and Table 3.

Table 2 Total production of bags per month before the Hungarian method is applied

\begin{tabular}{clcc}
\hline No & \multicolumn{1}{c}{ Name of Product } & $\begin{array}{c}\text { Number of hand } \\
\text { bags/day }\end{array}$ & $\begin{array}{c}\text { Number of bags } \\
\text { /month }\end{array}$ \\
\hline 1 & Hand bags of Mambo & 3 & 72 \\
2 & Hand bags of Lonjong & 2 & 48 \\
3 & Hand bags of Ransel & 1 & 24 \\
4 & Hand bags of Alexa & 3 & 72 \\
5 & Hand bags of Tampang Bunga & 2 & 48 \\
6 & Hand bags of Keong & 3 & 72 \\
7 & Hand bags of Tima & 2 & 48 \\
8 & Hand bags of Luna & 3 & 72 \\
9 & Hand bags of Mikha & 2 & 48 \\
10 & Hand bags of Elli & 1 & 24 \\
& Total & $\mathbf{2 2}$ & $\mathbf{5 2 8}$ \\
\hline
\end{tabular}

To determine the number of bags that can be produced per day is done by calculating the embroidery and finishing time of a bag. The duration of finishing for one bag is 60 minutes, while the employee works for 7 hours per day and in one month the employee works for 24 days, assuming that each type of bag is done by the same employee so the maximum production time for each bag is 420 minutes per day. After calculation, the following results are obtained:

Table 3 Monthly production of hand bags after applying the Hungarian method

\begin{tabular}{clccc}
\hline No & \multicolumn{1}{c}{ Name of products } & $\begin{array}{c}\text { Duration of } \\
\text { Embroidery } \\
\text { hand bags of }+ \\
\text { finishing (minutes) }\end{array}$ & $\begin{array}{c}\text { The number } \\
\text { of hand bags } \\
\text { / daily }\end{array}$ & $\begin{array}{c}\text { The number } \\
\text { of hand bags } \\
\text { / monthly }\end{array}$ \\
\hline 1 & Hand bags of Mambo & 135 & 3 & 72 \\
2 & Hand bags of Lonjong & 135 & 2 & 48 \\
3 & Hand bags of Ransel & 147 & 2 & 48 \\
4 & Hand bags of Alexa & 142 & 3 & 72 \\
5 & Hand bags of Tampang Bunga & 148 & 2 & 48 \\
6 & Hand bags of Keong & 159 & 2 & 48 \\
7 & Hand bags of Tima & 144 & 2 & 48 \\
8 & Hand bags of Luna & 135 & 3 & 72 \\
9 & Hand bags of Mikha & 137 & 3 & 72 \\
10 & Hand bags of Elli & 140 & 2 & 48 \\
& Total & & $\mathbf{2 4}$ & $\mathbf{5 7 6}$ \\
\hline
\end{tabular}

From both the Table 2 and the Table 3, it can be seen that in Table 2 the number of hand bags produced per day is 22 hand bags and the number of hand bags produced monthly is 528 , while in Table 3 after the scheduling arrangements using the Hungarian method on the process of embroidery the hand bags, it can be seen that The embroidery company produces 24 hand bags per day or 576 hand bags per-month . There is $9.09 \%$ increase. 


\subsection{Sensitivity Analysis}

\subsubsection{Non Base Variable}

Non-base variables in terms of assignment problems are all variables that have too high a cost so that it is not economical enough if it has to be chosen.

\section{Suppose}

$c_{i j(\text { old })}=$ coefficient or the amount of the $i$ th employee cost for the jth-job in the initial table.

$c_{i j(n e w)}=$ coefficient or the amount of the $i$ th employee cost for the $j$ th-job in the optimum table Then the range of bags of the bottom non-base coefficients can be formulated as follows:

$$
c_{i j}(\text { below })=c_{i j(\text { old })}-c_{i j(\text { new })}
$$

Whereas, the coefficients of non-base variables reach a very large number or $\infty$. So, if the coefficient of the non-base variable is increased for whatever values, it does not disturb the previous optimal results.

Table 4 Range of non-base coefficient variables

\begin{tabular}{cccccc}
\hline $\begin{array}{c}\text { Non Base } \\
\text { Variable } \\
\left(\boldsymbol{x}_{\boldsymbol{i} \boldsymbol{j}}\right)\end{array}$ & $\begin{array}{c}\text { The old of } \\
\text { Coefficient } \\
\text { of old Aim } \\
\left(\boldsymbol{c}_{\boldsymbol{i} \boldsymbol{j})}\right)\end{array}$ & $\begin{array}{l}\text { The } \\
\text { Coefficient } \\
\text { Of new } \\
\text { Aim }\left(\boldsymbol{c}_{\boldsymbol{i} \boldsymbol{j}}\right)\end{array}$ & $\begin{array}{l}\text { The hand } \\
\text { bags } \\
\text { material } \\
\text { from Bottom } \\
\left(\boldsymbol{c}_{\boldsymbol{i j} \text { bottom })}\right.\end{array}$ & $\begin{array}{c}\text { The material } \\
\text { of hand bags } \\
\text { from Top } \\
\left(\boldsymbol{c}_{\boldsymbol{i j} \text { top }}\right)\end{array}$ & $\begin{array}{c}\text { The range } \\
{\left[\left(\boldsymbol{c}_{\boldsymbol{i} \boldsymbol{j} \text { bottom }),}\right.\right.} \\
\left(\boldsymbol{c}_{\boldsymbol{i} \boldsymbol{j} \text { top })}\right)\end{array}$ \\
\hline$x_{12}$ & 131 & 54 & 77 & $\infty$ & {$[77, \infty)$} \\
$x_{13}$ & 130 & 52 & 78 & $\infty$ & {$[78, \infty)$} \\
$x_{14}$ & 95 & 20 & 70 & $\infty$ & {$[70, \infty)$} \\
$x_{15}$ & 100 & 28 & 72 & $\infty$ & {$[72, \infty)$} \\
$x_{17}$ & 142 & 53 & 89 & $\infty$ & {$[89, \infty)$} \\
$x_{18}$ & 110 & 33 & 77 & $\infty$ & {$[77, \infty)$} \\
$x_{19}$ & 150 & 70 & 80 & $\infty$ & {$[80, \infty)$} \\
$x_{110}$ & 87 & 12 & 75 & $\infty$ & {$[75, \infty)$} \\
$x_{21}$ & 120 & 45 & 75 & $\infty$ & {$[75, \infty)$} \\
$x_{22}$ & 132 & 55 & 77 & $\infty$ & {$[77, \infty)$} \\
$x_{24}$ & 120 & 45 & 75 & $\infty$ & {$[75, \infty)$} \\
$x_{25}$ & 140 & 68 & 72 & $\infty$ & {$[72, \infty)$} \\
$x_{26}$ & 110 & 26 & 84 & $\infty$ & {$[84, \infty)$} \\
$x_{27}$ & 95 & 6 & 89 & $\infty$ & {$[89, \infty)$} \\
$x_{117}$ & 127 & 38 & 89 & $\infty$ & {$[89, \infty)$} \\
$x_{118}$ & 140 & 63 & 77 & $\infty$ & {$[77, \infty)$} \\
$x_{1110}$ & 77 & 2 & 75 & $\infty$ & {$[75, \infty)$} \\
\hline
\end{tabular}

\subsubsection{Base Variable}

There are several steps to search the ranges for base variables, that must be considered:

1. Look at the optimal table, look for the bag thresholds that cause the optimal table not to be disturbed. The threshold value of these bags is the smallest non-base variable coefficient values.

2. Look for the variable range base.

3. The minimum number of bags of the base variable is:

$$
c_{i j}(\text { bottom })=c_{i j(\text { old })}-\Delta
$$

The maximum number of bags of the base variables is:

$$
c_{i j}(\text { top })=c_{i j(\text { old })}+\Delta
$$

So that the range of coefficients of the base variable is:

$$
\left[c_{i j(\text { old })}-\Delta, c_{i j(\text { old })}+\Delta\right]
$$


Table 5 Range of base coefficient variables

\begin{tabular}{|c|c|c|c|}
\hline Base Variables & $\begin{array}{c}\text { Minimum } \\
\text { Number of } \\
\text { Bags of the } \\
\text { Base } \\
\text { Variable } \\
{\left[c_{i j(\text { old })}-\Delta\right]}\end{array}$ & $\begin{array}{c}\text { Maximum } \\
\text { Number of } \\
\text { Bags of the } \\
\text { Base } \\
\text { Variable } \\
{\left[c_{i j(\text { old })}+\Delta\right]}\end{array}$ & $\begin{array}{c}\text { Range of Base Variables } \\
{\left[\boldsymbol{c}_{i j(\text { lama })}-\Delta, \boldsymbol{c}_{i j(\text { lama })}+\Delta\right]}\end{array}$ \\
\hline$x_{11}$ & $75-1=74$ & $75+1=76$ & {$[74,76]$} \\
\hline$x_{16}$ & $84-1=83$ & $84+1=85$ & {$[83,85]$} \\
\hline$x_{23}$ & $78-1=77$ & $78+1=79$ & {$[77,79]$} \\
\hline$x_{29}$ & $80-1=79$ & $80+1=81$ & {$[79,81]$} \\
\hline$x_{210}$ & $75-1=74$ & $75+1=76$ & {$[74,76]$} \\
\hline$x_{32}$ & $87-1=86$ & $87+1=88$ & {$[86,88]$} \\
\hline$x_{45}$ & $82-1=81$ & $82+1=83$ & {$[81,83]$} \\
\hline$x_{48}$ & $87-1=86$ & $87+1=88$ & {$[86,88]$} \\
\hline$x_{410}$ & $85-1=84$ & $85+1=86$ & {$[84,86]$} \\
\hline$x_{54}$ & $85-1=84$ & $85+1=86$ & {$[84,86]$} \\
\hline$x_{63}$ & $88-1=87$ & $88+1=89$ & {$[87,89]$} \\
\hline$x_{77}$ & $99-1=98$ & $99+1=100$ & {$[98,100]$} \\
\hline$x_{81}$ & $75-1=74$ & $75+1=76$ & {$[74,76]$} \\
\hline$x_{86}$ & $84-1=83$ & $84+1=85$ & {$[83,85]$} \\
\hline$x_{94}$ & $75-1=74$ & $75+1=76$ & {$[74,76]$} \\
\hline$x_{102}$ & $77-1=76$ & $77+1=78$ & {$[76,78]$} \\
\hline$x_{107}$ & $89-1=88$ & $89+1=90$ & {$[88,90]$} \\
\hline$x_{108}$ & $77-1=76$ & $77+1=78$ & {$[76,78]$} \\
\hline$x_{116}$ & $84-1=83$ & $84+1=85$ & {$[83,85]$} \\
\hline$x_{119}$ & $80-1=79$ & $80+1=81$ & {$[79,81]$} \\
\hline
\end{tabular}

The results of the sensitivity analysis can be seen in Table 4 so that the optimal assignment for all workers in the company will still be optimal in the specified timeframe. It can be seen that the value of $x_{11}$ means that the assignment of employee " 1 " to work " 1 " will still be an optimal assignment if the time length of doing the task is still within the working time span, namely [74,76]. And the value of $x_{119}$ means that the assignment of employee "11" to work "9" will still be an optimal assignment when the employee is working in the time span of $[79,81]$.

\section{Conclusion}

Based on the results of the discussion conducted, conclusions can be drawn as follow: the employee scheduling in working on hand bags of the company that can minimize processing time are: employees 1 working on the hand bags of Mambo, employees 2 working on the hand bags of Elli, employees 3 working on the hand bags of Lonjong, employees 4 working on the hand bags of Tampang Bunga, employees 6 working on the hand bags of Backpacks, employee 7 works on the hand bags of Tima, employees 8 work on the hand bags of Keong, employees 9 work on the hand bags of Alexa, employees 10 work on the hand bags of Luna, employees 11 work on the hand bags of Mikha, with a total processing time of 13.7 hours.

The total production of hand bags of the company before the Hungarian method was applied is 22 hand bags per day or 528 hand bags per month. After the Hungarian method was applied the amount of production was 24 hand bags per day or 576 hand bags per month, thus the production is increasing by $9.09 \%$. The results obtained from the sensitivity analysis of the company give the time span allowed for each base or non-base variable to maintain the optimal assignment. 
Acknowledgements

The authors would like to express their gratitude to colleagues in the Department of Mathematics at The University of North Sumatera who have organized the Semirata ICST MIPA Medan on 4-6 May 2018 and the reviewers who have given the authors the opportunity to submit this paper to be published in the proceeding/journals assigned for the conference.

\section{REFERENCES}

[1] H. A. Taha, Riset Operasi, Jakarta Binarupa Aksa, 1996.

[2] S. Mulyono, Riset Operasi, Lembaga Penerbit Fakultas Ekonomi Universitas Indonesia (LPFE-UI), Jakarta, 2004.

[3] R. Bronson, Theory and Problems of Operations Research, Schaum's Outline Series, McGraw-Hill, 1983.

[4] A. Revindran, D. T. Philips and J. Solberg, Operations Research Principles and Practice, 2nd ed., John Wiley \& Sons, Canada, 1987.

[5] H. Anton and C. Rorres, Aljabar Linier Elementer, Erlangga, Jakarta, 2004.

[6] J. Banks, J. S. Carson, B. L. Nelson and D. M. Nikol, Discrete-Event System Simulation, 4th ed., Prentice Hall, 2005.

[7] W. T. Bernard, Sains Manajemen, Pearson Education Asia, 2001.

[8] Hillier and Lieberman, Introduction to Operations Research, 8th ed., McGraw Hill, 2005.

[9] A. M. Law and W. D. Kelton, Simulation Modeling and Analysis, McGraw Hill, New York, USA, 2000 